\title{
International Movement of Japan's Pharmaceutical Industry: Reform of Japanese Health Policies, Part III
}

There are about 1,550 pharmaceutical companies in Japan, of which approximately 450 supply drugs for medical care.' Most of the large companies, such as Takeda, Fujisawa, and Tanabe, began as traditional wholesalers, and thus have developed more strength in sales promotion than in scientific research. ${ }^{2}$ Japan has a corresponding history of importing foreign products and selling them in the domestic market. Because the Japanese market grew rapidly with the implementation of national health insurance and was protected by the National Industrial Policy, Japanese pharmaceutical companies did not develop an institutional capacity to market their products in over-

Kimiko Chevalier and J. Warren Salmon

\section{Authors}

KIMIKO CHEVALIER, PHARM.D., received her nurse-midwife training and worked in the Japanese health care system for several years. She was awarded her Pharm.D. degree in May from the University of Illinois at Chicago. J. WARREN SALMON, PH.D., is Professor of Pharmacy Administration at the University of lllinois at Chicago. He is Contributing International Editor for JMCP.

Copyright $(1998$, Academy of Managed Care Pharmacy, Inc. All right reserved. seas markets nor did they innovate internationally acceptable drugs until the 1980s. At that time, the government was curbing drug prices to reduce health expenditures, and competition with foreign firms for the domestic market was increasing. Pressures on Japanese drug companies to develop domestic drug products and to market them internationally intensified.

That historical focus on the domestic market resulted in a lack of overseas experiences and understanding among the top management of Japan's pharmaceutical firms. Foreign language competencies are essential for overseas drug marketing activities because of the massive amounts of information required for drug approval and marketing and the high degree of government regulation; U.S. Food and Drug Administration regulations have been particularly problematic for Japanese companies. Japanese firms thus have used licensing or joint ventures to introduce their products overseas and have depended on the regulatory expertise of their U.S. partners to achieve approvals.

In contrast to their sophisticated understanding of marketing automobiles, electronics, and now computers in the United States, the Japanese are just now becoming skilled in the American pharmaceutical market. Furthermore, a stronger yen in the 1980s lowered some costs of overseas market entry, especially land and labor, making it more attractive for Japanese companies to establish wholly owned subsidiaries, manufacturing plants, and research facilities in foreign countries. Today, changing economic conditions are altering manufacturers' strategies yet again.

This article examines the context of this overseas development, which was the focus of Part Il of this series (published in the March/April 1998 issue of JMCP). ${ }^{3}$ Part III includes a relevant update following the recent financial turmoil across the Pacific Rim and discusses specific activities of Japanese pharmaceutical firms as they have ventured into overseas markets, including their entry into the American managed care arena. The contemporary period presents a great deal of uncertainty as Japanese manufacturers regroup to adjust to new market conditions domestically and to continued expansion overseas.

J. Warren Salmon, Ph.D. International Contributing Editor

$\Lambda$ ccording to a survey conducted by the Japan Pharmaceutical Manufacturers Association in March 1993, 41 member firms were engaged in overseas activities: 38 firms in research and development ( $R \& D$ ) and 20 firms in production, with some overlap between the two categories. ${ }^{4}$ Expenses for overseas $R \& D$ made up $3.3 \%$ of the total R\&D budget of 38 firms; six firms spent more than $10 \%$ of their $\mathrm{R} \& \mathrm{D}$ funds in overseas research activities. ${ }^{5}$

The number of overseas bases has grown rapidly, totaling 245 in March 
Table 1. Overseas Bases of Pharmaceutical Firms as of March 1993 (March 1991 in parentheses)

\begin{tabular}{|c|c|c|c|c|c|c|c|}
\hline Area Form of Base & N. America & W. Europe & Asia \& Oceania & Central \& S. America & Russia \& E E. Europe & Middle East \& Africa & Total \\
\hline Wholly owned subsidiaries & $36(19)$ & $34(16)$ & $13(10)$ & $2(2)$ & $-(-)$ & $-(-)$ & $85(47)$ \\
\hline Capital participation & $6(6)$ & $8(15)$ & $8(7)$ & 2(4) & $-(-)$ & $-(-)$ & $24(32)$ \\
\hline Joint ventures & $2(4)$ & $13(11)$ & $46(36)$ & $-(-)$ & $-(-)$ & $1(1)$ & $24(32)$ \\
\hline Branches and offices & $20(16)$ & $28(30)$ & $24(11)$ & $1(-)$ & $1(1)$ & $-(-)$ & $74(58)$ \\
\hline Total & $64(45)$ & $83(72)$ & $91(64)$ & $.5(6)$ & $1(1)$ & $1(1)$ & $245(189)$ \\
\hline
\end{tabular}

Source: JAPAN 21st August 1995

1993 compared to 189 in March 1991. Although their presence in Central and South America, Russia and Eastern Europe, the Middle East, and Africa has been negligible, Japanese companies have established solid bases in Asia and Oceania (9l firms), Western Europe (83 firms), and North America (64 firms). Japanese drug companies established 36 wholly owned subsidiaries in North America and 34 in Western Europe, with 20 company branches in North America and 28 in Western Europe. Asia and Oceania led joint ventures with 46 firms $^{4}$ (see Table 1).

Japanese pharmaceutical companies already have made an impression around the world. The U.S. Department of Commerce has stated, "U.S. and European firms appear to be betting that the top Japanese companies will eventually make the transition to world-class competitors."

Although the information on individual firms spotlighted in the following discussion may be dated or incomplete, it remains one of the few compilations in English documenting their overseas activity to date. Because current conditions in Japan may be altering these strategies individually and/or collectively, the following information can give insight into past behaviors of the 10 Japanese firms on the international scene and should be useful for assessing future strategies. Table 2 ranks the 10 major Japanese pharmaceutical companies by overseas sales, and Table 3 offers a timeline of overseas base development for each of the top 10 firms.

\section{TAKEDA CHEMICAL INDUSTRY, LTD.}

Takeda Chemical Industry, Ltd., was founded 215 years ago and ranks at the top of the pharmaceutical enterprise in

Table 2. Ten Largest Japanese Pharmaceutical Firms (in million yen)

\begin{tabular}{l|c|c|c|c|c|c|c|c|c}
\hline Company & Term & Sales & Growth Rate & Operating Profit & Growth Rate & Ordinary Profit & Growth Rate & Net Profit & Growth Rate \\
\hline Takeda & 3 & 574,367 & $2.3 \%$ & 67,843 & $1.6 \%$ & 78,809 & 2.1 & 39,809 & $7.4 \%$ \\
\hline Sankyo & 3 & 401,466 & $1.5 \%$ & 82,244 & $0.5 \%$ & 83,526 & 3.9 & 37,250 & $1.0 \%$ \\
\hline Yamanouchi & 3 & 273,048 & $5.1 \%$ & 56,419 & $11.5 \%$ & 57,990 & 6.6 & 28,143 \\
\hline Fujisawa & 3 & 241,483 & $2.8 \%$ & 25,036 & $46.0 \%$ & 24,009 & 20.4 & 7,474 & $25.7 \%$ \\
\hline Eisai & 3 & 240,030 & $7.0 \%$ & 36,913 & $12.7 \%$ & 36,982 & 12.4 & 16,888 & $7.1 \%$ \\
\hline Shionogi & 3 & 238,176 & $3.5 \%$ & 23,057 & $18.2 \%$ & 26,192 & 13.7 & 11,471 & $11.1 \%$ \\
\hline Daiichi & 3 & 221,819 & $2.1 \%$ & 38,166 & $11.2 \%$ & 41,666 & 8.7 & 18,876 & $10.6 \%$ \\
\hline Taisho & 3 & 210,936 & $5.3 \%$ & 49,727 & $18.0 \%$ & 55,602 & 7.7 & 27,563 & $9.9 \%$ \\
\hline Tanabe & 3 & 183,162 & $0.2 \%$ & 10,991 & $33.1 \%$ & 10,515 & 27.7 & 3,122 & $8.8 \%$ \\
\hline Chugai $^{*}$ & 12 & 162,588 & $7.4 \%$ & 19,756 & $13.1 \%$ & 19,886 & 16.8 & 7,608 & $8.3 \%$ \\
\hline
\end{tabular}

*Dec. '94 term for Chugai Pharmaceutical only; March '95 term for all other firms. 
International Movement of Japan's Pharmaceutical Industry: Reform of Japanese Health Policies, Part III

Continued from page 568

Table 3. Overseas Bases by Major Japanese Pharmaceutical Companies

\begin{tabular}{|c|c|c|c|c|}
\hline Company & Category* & Year & Development of Major Overseas Bases & $\begin{array}{c}\text { Candidates of } \\
\text { International Drugs }\end{array}$ \\
\hline Takeda & $\begin{array}{l}1 \\
3\end{array}$ & $\begin{array}{l}1985 \\
1988 \\
1994\end{array}$ & $\begin{array}{l}\text { Strongholds for production and marketing established in Southeast } \\
\text { Asian countries. } \\
\text { Laboratories Takeda established by joining with Roussel Uclaf in France. } \\
\text { Takeda Pharma GmbH established by joining with Grunenthal } \\
\text { GmbH in Germany. } \\
\text { Takeda Italia Farmaceutici established by joining with Cynamid Italia } \\
\text { S.P.A. in Italy. } \\
\text { TAP/Pharmaceuticals established by joining with Abbott Laboratories } \\
\text { in the U.S. } \\
\text { Takeda Europe R\&D Center founded in Frankfurt, Germany. } \\
\text { Tianjin Takeda Pharmaceuticals Co., Ltd., joined with Lisheng } \\
\text { Pharmaceutical Factory, Tianjin, China. } \\
\text { Takeda has wholly owned subsidiaries and joint companies in } 10 \\
\text { countries. }\end{array}$ & $\begin{array}{l}\text { Leuplin ( } \mathrm{Tx} \text { for prostate cancer) } \\
\text { Takepron (proton pump inhibitor) }\end{array}$ \\
\hline Sankyo & $\begin{array}{l}3 \\
3 \\
3 \\
3 \\
3 \\
2 \\
1 \\
4 \\
4 \\
4 \\
3\end{array}$ & $\begin{array}{l}1990 \\
1992\end{array}$ & $\begin{array}{l}\text { Sankyo Europe GmbH in Dusseldorf, Germany, established. } \\
\text { Sankyo U.S.A. Corp. in New York established. } \\
\text { Uni Sankyo founded in India. } \\
\text { Sino-Japanese Synthetic Chemistry, Ltd., established in Taiwan. } \\
\text { Thai Sankyo founded in Thailand. } \\
\text { Capital invested in Luitpold Werk, German pharmaceutical company. } \\
\text { Luitpold Pharma GmbH in Munich, Germany, established by fully } \\
\text { purchasing Luitpold Werk. } \\
\text { Joint research with University of California in U.S.A. established. } \\
\text { Joint research with Medical Research Council in London and } \\
\text { University of Southern California in U.S.A. established. } \\
\text { Beijing office opened. } \\
\text { Joint venture founded with Glycomed Inc. \& Reagando Co. in U.S. }\end{array}$ & $\begin{array}{l}\text { Mevalotin (antihyperlipidemia drug) } \\
\text { Noscal (antidiabetes drug) } \\
\text { Acecol (antihypertensive drug) }\end{array}$ \\
\hline Yamanouchi & $\begin{array}{l}4 \\
4 \\
4 \\
1\end{array}$ & $\begin{array}{l}1963 \\
1986 \\
1989 \\
1990 \\
1990 \\
1990 \\
1991\end{array}$ & $\begin{array}{l}\text { Yamanouchi Taiwan Co., Ltd., established by joining with } \\
\text { Yamanouchi Pharmaceutical Co., Ltd. } \\
\text { Yamanouchi Ireland Co., Ltd., in Ireland established. } \\
\text { Japan Shacklee Corp. constituted by purchasing Shacklee } \\
\text { Corp., U.S. } \\
\text { Yamanouchi Research Institute installed at Oxford in England. } \\
\text { Korea Yamanouchi Pharmaceutical in Seoul, Korea, established. } \\
\text { Hong Kong office opened. } \\
\text { Royal Gist-Brocades Nv, medical drug division of foods and } \\
\text { chemicals company in Netherlands, purchased and renamed } \\
\text { Brocades Pharma to Yamanouchi Europe. } \\
\text { Capital invested in Roberts, Inc. in U.S. } \\
\text { Beijing office opened. } \\
\text { Yamanouchi Europe again renamed Yamanouchi Pharma and } \\
\text { established sales branched in } 12 \text { countries, including France, } \\
\text { Germany, and Russia. } \\
\text { Yamanouchi Shenyang Pharmaceutical Co., Ltd., established, build- } \\
\text { ing Shenyang First Pharmaceutical Factory in Shenyang, China. }\end{array}$ & $\begin{array}{l}\text { Gaster (antiulcer drug) } \\
\text { Perdipine (circulation-improving } \\
\text { drug) } \\
\text { Harnal (urination-improving drug) } \\
\text { Atock (bronchial dilator) }\end{array}$ \\
\hline
\end{tabular}


Table 3. Overseas Bases by Major Japanese Pharmaceutical Companies (continued)

\begin{tabular}{|c|c|c|c|c|}
\hline Company & Category* & Year & Development of Major Overseas Bases & $\begin{array}{c}\text { Candidates of } \\
\text { International Drugs }\end{array}$ \\
\hline Fujisawa & $\begin{array}{l}1 \\
4 \\
3 \\
2 \\
2 \\
4 \\
4 \\
1 \\
1\end{array}$ & $\begin{array}{l}1977 \\
1979 \\
1981 \\
1983 \\
1985 \\
1985 \\
1986 \\
1987 \\
1987 \\
1989 \\
1989 \\
1990 \\
1990 \\
1991\end{array}$ & $\begin{array}{l}\text { Fujisawa Pharmaceutical Corp. in U.S. established. } \\
\text { London office opened. } \\
\text { Fujisawa SmithKline Corp. established as joint venture. } \\
\text { Capital invested in Klinge Pharma GmbH, German pharmaceutical co. } \\
\text { Capital invested in Lyphomed Inc., American pharmaceutical co. } \\
\text { Clinical Research Center opened. } \\
\text { Milan office opened. } \\
\text { Fujisawa SmithKline Corp. wholly consolidated. } \\
\text { Fujisawa Holland B.V. founded. Maryland Representative Office in } \\
\text { U.S. opened. } \\
\text { Lyphomed Inc. totally acquired. } \\
\text { Fujisawa SmithKline Corp. renamed Fujisawa Pharmaceutical Co. } \\
\text { Fujisawa USA, Inc. established by merging with Lyphomed Fujisawa } \\
\text { Pharmaceutical company \& Maryland Representative Office. } \\
\text { Fujisawa Ireland Limited founded. } \\
\text { Fujisawa Europe GmbH founded. }\end{array}$ & $\begin{array}{l}\text { Prograf (immunosuppressant) } \\
\text { Cefamedin (antibiotic) }\end{array}$ \\
\hline Eisai & $\begin{array}{l}4 \\
4 \\
3\end{array}$ & $\begin{array}{l}1988 \\
1989 \\
1992\end{array}$ & $\begin{array}{l}\text { Eisai America Inc. established. } \\
\text { Eisai Research Institute of Boston in Andover, Massachusetts, in } \\
\text { U.S. established. } \\
\text { Eisai London Research Laboratories at University College in } \\
\text { London, U.K., established. } \\
\text { Eisai Corporation in New Jersey founded. } \\
\text { Joint venture founded with Sandoz Pharmaceutical in Germany. }\end{array}$ & $\begin{array}{l}\text { Candidates of international drugs are } \\
\text { undergoing clinical tests. }\end{array}$ \\
\hline Daiichi & $\begin{array}{l}3 \\
3 \\
4\end{array}$ & $\begin{array}{l}1993 \\
1993\end{array}$ & $\begin{array}{l}\text { Subsidiaries established in U.S., U.K., Germany, Taiwan, and Hong Kong. } \\
\text { Joint ventures founded within France, South Korea, Taiwan, and } \\
\text { Thailand. } \\
\text { Representative offices maintained in U.S., U.K., Germany, Taiwan; } \\
\text { and Hong Kong. } \\
\text { Daiichi Research Center at University of California at San } \\
\text { Francisco founded. } \\
\text { Daiichi Pharmaceutical (Thailand) Limited established. } \\
\text { Joint ventures founded with Shanghai Shin Yi Pharmaceutical } \\
\text { Corp. Ltd. and Beijing Pharmaceutical Works No. } 4 . \\
\text { Beijing office opened. }\end{array}$ & $\begin{array}{l}\text { Tarivid (broad-spectrum antibiotic) } \\
\text { Cravit (broad-spectrum antibiotic) } \\
\text { Transamin (antiplasmin agent) } \\
\text { Neuer (gastric mucosal defensive } \\
\text { drug) }\end{array}$ \\
\hline Chugai & $\begin{array}{l}4 \\
4 \\
3\end{array}$ & $\begin{array}{l}1989 \\
1992 \\
1993 \\
1994\end{array}$ & $\begin{array}{l}\text { Gen-probe in U.S., the world's top-class maker of diagnostic } \\
\text { biodrugs, purchased. } \\
\text { C\&C Research Laboratories established by joining with } \\
\text { Choongwae, South Korean pharmaceutical company. } \\
\text { Stocks acquired from Amrad, Australian pharmaceutical company. } \\
\text { Joint venture founded with Shanghai xim xing Medicine \& Drug } \\
\text { Scientific Development Center in China. } \\
\text { Laboratories founded in Korea, Australia, and in San Diego in U.S.. } \\
\text { Chugai Pharmaceutical BioPharmaceuticals Inc. established. } \\
\text { Joint venture founded with Rhone-Poulenc in France. }\end{array}$ & $\begin{array}{l}\text { Ulcerlmin (Tx for gastritis) } \\
\text { Granocyte (Tx for Leukopenia) } \\
\text { Picibanil (anticancer drug) } \\
\text { Sigmart (Tx for angina) } \\
\text { Alfarol (calcium-bone metabolizer) }\end{array}$ \\
\hline
\end{tabular}

*Category Number: 1. Wholly owned subsidiaries; 2. Capital participation; 3. Joint ventures; 4. Branches and offices. 
Japan. $^{7}$ Their overseas activity has been expanding, achieving annual sales of $\$ 5.57$ billion ( 574 billion yen) in March of $1995 .{ }^{.}$Recently, Takeda has concentrated on reinforcing tripartite research strongholds covering Japan, the United States, and Europe to construct a global network and establish the foundation of an international enterprise based on research and development.

In 1978, Takeda established the first French-Japanese joint enterprise, Laboratories Takeda, with Roussel Uclaf. The company soon followed this joint venture with the formation of Takeda Pharma GmbH in Germany and Takeda Italia Farmaceutici in Italy. In 1985 , Takeda opened TAP Pharmaceu-ticals as its center in the United States, achieving considerable success with clinical development functions as a joint venture with Abbott Laboratories. In February 1988, Takeda Europe R\&D Center was founded in Frankfurt, Germany, as a stronghold for new drug development in Europe. ${ }^{7}$

Kenkichi Murakami, director of Takeda Chemical Industry, Ltd., has emphasized the importance of developing the R\&D capability to create innovative new drugs. ${ }^{7}$ Takeda has focused on developing innovative drugs in seven therapeutic areas: dementia, hypertension, osteoporosis, ulcers, cancer, diabetes, and infectious diseases. Leuplin, a therapeutic drug for prostate cancer and endometriosis, and Takepron, a proton pump used for duodenal ulcer and reflux esophagitis, already are marketed in Europe and the United States and have been very important to the overseas business of Takeda Chemical Industry, Ltd. In addition, several new drugs are in application for approval, with some in clinical trials overseas.

Takeda, which markets products such as Cephem antibiotics in China, established a joint venture contract with Lisheng Pharmaceutical Factory Tianjin in 1994 to create Tianjin Takeda Pharmaceutical Co., Ltd., with Takeda contributing $75 \%$ of the $\$ 19.2$ million capitalization. ${ }^{7}$ A pharmaceutical plant was scheduled to be completed in 1996. Takeda now has wholly owned subsidiaries and joint concerns in 10 countries, including China. The company believes that the merits of international venture are not in scale but in quality, especially in developing globally acceptable new drugs.

\section{SANKYO COMPANY, LTD.}

At the end of March 1995, Sankyo Co., Ltd., reported total sales of $\$ 3.9$ billion (401 billion yen), including exports of $\$ 301$ million (31 billion yen), with a growth rate of $1.5 \%$. Sankyo's ordinary profit totaled 83.5 billion yen, a $3.9 \%$ growth rate. Sankyo ranks as the second largest pharmaceutical firm in Japan.'

Sankyo has developed several remarkable new drugs. Mevalotin, used to treat hyperlipidemia, earns $\$ 971$ million (100 billion yen) a year in its domestic market and is sold in 47 Western countries through BristolMyers Squibb Company. The annual turnover of Mevalotin in the United States alone already has reached $\$ 311$ million ( 32 billion yen). Mevalotin works to decrease LDL cholesterol by inhibiting HMG-CoA reductase and also to increase HDL cholesterol. ${ }^{8}$ Tomonori Miki, executive managing director of Sankyo, has said that the company intends to begin a self-controlled marketing system in the United States and begin full-scale sales activities rather than licensing Bristol-Myers Squibb Company to sell Mevalotin throughout the world. ${ }^{9}$

Sankyo plans to follow the success of Mevalotin by marketing Noscal for diabetes and Acecol for hypertension in Europe, the United States, and other countries. The company, which conducts its own R\&D, has no research organization abroad because its laboratories in Shinagawa, Tokyo, and its association with Tsukuba Research Laboratories in Kyshu suffice. However,
Sankyo is pushing joint research on Alzheimer's disease with the Medical Research Council in London and the University of Southern California. Additionally, in 1994 Sankyo began working with the University of Alabama on research into rheumatism and malignancies that cause autoimmunization.

With its purchase of Munich-based Luitpold Werk in 1992-now called Luitpold Pharma GmbH-Sankyo secured footholds for production, marketing, $R \& D$, and the expansion of its international network through Luitpold's subsidiaries in Europe and North and South America. Sankyo has offered technical licenses to the Upjohn Co. in the United States for the production and sale of its antibiotics Cefmetazon and Banan. Sankyo's other international activities are managed through Sankyo Europe GmbH in Germany, Sankyo U.S.A. in New York, Uni Sankyo in India, Sino-Japanese Synthetic Chemistry, Ltd., in Taiwan, and Thai Sankyo in Thailand. Sankyo now is gathering information through its Beijing office to enable the company to expand its operations in China.

Sankyo moved quickly into the international marketplace; however, it will take time for Sankyo to build international $R \& D$, production, and sales networks on an integrated basis Sankyo will expand overseas markets step by step, with promising new drugs as the core of its marketing strategy.

\section{YAMANOUCHI PHARMACEUTICAL COMPANY, LTD.}

In fiscal year 1994, Yamanouchi Pharmaceutical Co., Ltd., achieved total sales of $\$ 2.65$ million (273 billion yen); exports accounted for $\$ 126$ million (12.7 billion yen). Ordinary profits totaled $\$ 563$ million ( 57.9 million yen). The sales and profits grew by $5.1 \%$ and $6.6 \%$, respectively. The combined organization, including 54 subsidiaries, showed sales of $\$ 3.7$ million (384 billion yen) 
and $\$ 748$ million (77.3 billion yen), up $4.2 \%$ and $10.5 \%$, respectively. ${ }^{10}$

Yamanouchi is actively pursuing business development in North America, Europe, and Asia. Consolidated pharmaceutical sales of 336.4 billion yen ( $\$ 3$ billion) in FY96 were up 8\%, due in part to contributions from international subsidiaries in Europe and Ireland. ${ }^{11}$ Yamanouchi was one of the first Japanese pharmaceutical corporations to build plants and laboratories in Europe. In 1986, the company established its subsidiary, Yamanouchi Ireland. Its Irish manufacturing plant has played a vital role in sales and production of the circulation-improving agent Perdipine and the antiulcer agent Gaster, sold in more than 100 countries with annual sales of $\$ 1.2$ billion worldwide in $1994 . .^{12}$ In 1990 , the Yamanouchi Research Institute was established at Oxford, where British scientists have been engaged in basic research on cell biology.

In 1991, Yamanouchi purchased the pharmaceutical division of Royal GistBrocades in the Netherlands as a stronghold for $R \& D$, drug manufacturing, and sales in Europe. This subsidiary, now called Yamanouchi Pharma, became a head office with sales branches in 12 countries, including France, Germany, and Russia. In addition, a new laboratory was completed in the Netherlands and a plant in Italy.

In 1989, Yamanouchi purchased Shacklee Corporation, a San Franciscobased company that markets enriched foods. Since that purchase, the company has achieved very high sales and profits. In 1992, Yamanouchi purchased a 29\% interest in Roberts, Inc., a midsized American pharmaceutical company. Yamanouchi USA is engaged in clinical development and study, including advanced research in a technical joint venture with Tularik Inc. of the United States, which possesses a gene transcription and screening technology.

In Southeast Asia, Yamanouchi created the joint venture Yamanouchi
Taiwan Co., Ltd., in 1963, and its Taipei Branch in 1987. The Seoul Office in Korea and the Hong Kong Office were founded in 1990. The Beijing Office, founded in 1993, has actively maneuvered for technological establishment and product exports in local pharmaceutical firms. In June 1994, Yamanouchi contributed $80 \%$ of the 3 billion yen capitalization to build Shenyang First Pharmaceutical Factory, a joint venture with China's Shenyang Pharmaceutical Co. ${ }^{13}$ The plant began full-scale operation in early 1997 to produce Gaster and Harnal, a urination-improving agent. This subsidiary hopes its first factory will become one of China's top three drug makers within several years ${ }^{14}$ by marketing Josamycin (an antibiotic), Gaster, Harnal, Perdipine, Atock (for asthma), Bisphonal (for hyperkalemia), and Elen (for dementia). Construction of another factory is scheduled for early next century. In 1996, Yamanouchi signed licensing agreements with NovoNordisk and Mallinckrodt.

Masayoshi Onoda, president of Yamanouchi Pharmaceutical Co., Ltd., said that the aim of the firm is to become a global enterprise, with the highest level of $R \& D$ capability in the world, by the first decades of the 21st century. According to Onoda, the immediate goal of $R \& D$ is to "deliver seven major new products to world market by 2005." 15 Yamanouchi believes that Harnal, which was developed in Japan in August 1993 and achieved sales of $\$ 146$ million (15.2 billion yen), will become the next internationally accepted drug. ${ }^{12}$ The firm's most emphasized research topics are dementia senilis, hypertension, cardiac diseases, and diabetes. Onoda also said that Yamanouchi's management tasks involve not only developing internationally acceptable new drugs and the reinforcing of enterprise competitiveness and profitability, but also maintaining prices of existing drugs and future cost savings. ${ }^{15}$

\section{FUJISAWA PHARMACEUTICAL COMPANY, LTD.}

Fujisawa Pharmaceutical Co., Ltd., had sales of $\$ 2.3$ billion (241.4 billion yen) in 1994 and is ranked fourth among Japanese pharmaceutical companies. ${ }^{1}$ Consolidated prescription sales for fiscal year 1996 were 230.2 million yen ( $\$ 2$ billion); drug products represented $86.5 \%$ of total consolidated sales.$^{16}$ Fujisawa wants to be ranked in the top 20 enterprises in the world and to firmly establish business in the United States and Europe through selfmarketing by the beginning of the $21 \mathrm{st}$ century, according to its chairman, Dr. Tomokichiro Fujisawa. ${ }^{17}$

Fujisawa developed a new immunosuppressant, Prograf (FK506), which began marketing in 1994 after approval in the United States by the Food and Drug Administration (FDA). Prograf also has been approved in the United Kingdom and Germany for treatment of rejection after liver and kidney transplants. ${ }^{17}$ Fujisawa has licensed Cephalosporin antibiotics to various countries in the world; however, Prograf was the first new drug developed and marketed solely by Fujisawa, and it is expected to play an important role in building international business.

In 1990, Fujisawa USA, Inc., was founded by merging Lyphomed (a pharmaceutical company acquired in 1989), the joint venture Fujisawa Pharmaceutical Company, and the company's Maryland Representative Office, which opened in 1987 as a center for product development.

In Europe, Fujisawa has built a number of strongholds: the London Office in 1979 for collecting information and surveying, and its Clinical Research Center in 1985 as a development center; the Milan Office in 1986; capital investment in the German pharmaceutical firm Klinge Pharma GmbH; and Fujisawa Holland B.V. in 1987 as a finance business. In addition, Fujisawa Ireland Limited was established in 
International Movement of Japan's Pharmaceutical Industry: Reform of Japanese Health Policies, Part IIl

Continued from page 576

1990 for ethical drug production and marketing, and in 1991, Fujisawa Europe GmbH was founded to supervise stocks in firms of Fujisawa Group in Europe.

Fujisawa's business strategies call for establishing its own bases in the European and U.S. markets through wholly owned, affiliated, or consolidated companies, investment in local enterprises, or license-based marketing. The firm seeks to make every effort to develop internationally acceptable drugs. Its consolidated R\&D spending in fiscal year 1996 was 36.4 billion yen, down $1 \%$ from the previous year.

\section{EISAI}

Eisai had annual sales amounting to $\$ 2.3$ billion ( 240 billion yen) as of March 1995 and was ranked fifth in Japan and 32nd among the world's pharmaceutical manufacturing companies. ${ }^{18}$ Masaji Ohno, a managing director and head of Eisai's R\&D department, said that the company will try to join the top 20 international firms early in the 21 st century, a goal whose success depends on development of new drugs.

Eisai has established a tripolar research base for $R \& D$ : the independent Tsukuba Research Laboratories, which was established in 1982 in Tsukuba Acadèmic New Town as a center for new drugs; Eisai Research Institute of Boston in Andover, Massachusetts, in 1989; and Eisai London Research Laboratories at University Colege in London in 1992. Also, Eisai America Inc., established in 1988, and London's Eisai Europe Ltd. are conducting basic organic research.

Eisai has not yet introduced outstanding internationally acceptable new drugs, but several candidates are undergoing clinical tests in the United States and Europe. These products include E2020 for the treatment of Alzheimer's disease; E3810 for ulcer; E5531 for the treatment of septicemia; and E5510 for the prevention of platelets.
In Europe and North America, the Eisai Corporation of North America serves as the core of operations. In Southeast Asia, the international department of Eisai's main office carries out detailed activities and exchanges information. Eisai is promoting fundamental and investigative research in a tripolar effort with Japan, the United States, and Europe and is solidifying its progress toward becoming an international enterprise.

\section{DAIICHI PHARMACEUTICAL COMPANY, LTD.}

Daiichi Pharmaceutical Co., Ltd., recorded annual sales of $\$ 2.15$ billion (221.8 billion yen) and ordinary profits of $\$ 408$ million ( 41.6 billion yen) as of March 1995. The company's total income and profit increased $2.1 \%$ and $8.7 \%$, respectively, from the previous fiscal year. ${ }^{19}$ In 1995, Daiichi ranked seventh largest among Japan's pharmaceutical firms. According to President Tadashi Suzuki, Daiichi emphasizes "high technology" and "globalization" to not only strengthen its domestic base, but also to work toward international expansion. ${ }^{20}$

Daiichi has subsidiaries in the United States, the United Kingdom, Germany, Taiwan, and Hong Kong, and joint ventures with local pharmaceutical companies in France, South Korea, Taiwan, and Thailand. The company maintains representative offices in each subsidiary. Daiichi has emphasized production and sales activities, particularly in Southeast Asia and China. In 1993, the company set up a joint venture, Daiichi Pharmaceutical Thailand Limited, to strengthen sales in the Southeast Asian market. In 1994, Daiichi began a business venture with Shanghai Shin Yi Pharmaceutical Corporation Limited and Beijing Pharmaceutical Works No. 4 to manufacture Tarivid tablets in China.

Daiichi's global R\&D strategy aims to strengthen its research bases and enhance exchanges with international researchers. In 1993, Daiichi founded the Daiichi Research Center at the University of California at San Francisco to conduct basic research on the causes of atherosclerosis. Daiichi conducts research in seven principal areas: antiinfective, anticancer, cardiovascular, central nervous system, gastrointestinal, immunity allergy, and contrast media. R\&D activities are centralized in the Tokyo R\&D Center.

Daiichi has developed several internationally acceptable new pharmaceuticals that have been distributed overseas, such as Tarivid and Cravit, new quinoline-type synthetic broad antibacterial agents; Transamin, an antiplasmin agent; and Neuer, a gastric mucosal defensive agent for gastric ulcer. Tarivid is available in 109'markets globally and has been licensed to Johnson \& Johnson in the United States and Hoechst of Germany. Domestic sales of Tarivid totaled $\$ 126$ million (13.1 billion yen), while exports totaled $\$ 68$ million (7.1 billion yen) in 1994. Cravit was developed as a successor to Tarivid and released on the domestic market in December 1993; it achieved sales of $\$ 369$ million ( 37.6 billion yen) in 1994. The combined sales of these drugs will surpass $\$ 534$ million (55 billion yen). ${ }^{19}$

In 1994, Daiichi's exports accounted for more than 18.9 billion yen, or $9.1 \%$ of sales. The company wants to raise its proportion of exports to sales to $20 \%$ in the coming years. ${ }^{20}$ Tarivid and Cravit have already established an international reputation and provide support to the growth of Daiichi's foundation in the international market.

\section{CHUGAI PHARMACEUTICAL COMPANY, LTD.}

Chugai Pharmaceutical Co., Ltd., reported total sales in 1994 of $\$ 1.58$ billion ( 162 billion yen) and a growth rate of $7.4 \%$. At that time, Chugai ranked 10th among Japanese pharmaceutical companies. ${ }^{21}$ 
Chugai's primary research areas include malignant tumors (including the relationship of malignancy to viruses and genetics), bone metabolism (such as osteoporosis), and the cardiovascular system. Research on blood and the immune system also is emphasized.

Chugai focuses on the development of new drugs that act at the genetic level. In 1989, Chugai acquired a powerful research center in the United States when it bought Gen-probe, which has achieved success with DNA probe diagnostics. Gen-probe has a large share of the diagnostics market and also has begun to develop several medical products, including G-CSF drugs and HIV drugs. In Europe, Chugai markets the G-CSF drug Granocyte for the treatment of leukopenia through Rhone-Poulenc, a French pharmaceutical company. Granocyte already has been marketed in several other European nations.

In 1992, Chugai built the C\&C Research Laboratories, a joint venture with Choongwae, a South Korean phar maceutical company. Choongwae manages manufacturing and sales of Granocyte; Picibanil, an anticancer drug; Sigmart for angina; Alfarol, a calciumbone metabolizer; and Ulcerlmin for gastritis and peptic ulcers. Chugai also has a contract for joint exploratory research with the Korean Chemistry Research Laboratory, which was founded in 1976 to provide the Korean chemical industry with $R \& D$ in a wide range of chemical technologies. In addition, in 1993 Chugai provided 61\% of the $\$ 5$ million start-up capital for a joint venture in Shanghai to export Chugai products, as well as to import, manufacture, and sell various drugs.

Chugai is expanding exploratory research to the Pacific Rim. The company has begun a joint venture with Amard, an Australian pharmaceutical company founded in 1986. Although the Pacific Rim has very little of the infrastructure needed for R\&D and a relative scarcity of human resources, "the Pacific Rim will be seen not only as a market in the future, but also as a treasure trove of resources for R\&D," said Osamu Nagayama, president of Chugai Pharmaceutical Co., Ltd. ${ }^{21}$ Chugai gave Amard marketing rights to G-CSF drugs in 1991 and acquired some of Amard's stock and marketing rights in Taiwan, Korea, and Japan.

According to Nagayama, the Japanese pharmaceutical industry has entered the age of "multinationalism" and "multiculturalism" by establishing research centers and personnel resources not only in Japan but also in other countries. Chugai believes it must work with other cultures to achieve international success.

\section{SUMMARY OF OVERSEAS ACTIVITY}

As a strategy for the 21st century, Japanese pharmaceutical companies have been shifting their targets from the domestic market to global markets, especially North America, Western Europe, and Asia. This shift will affect $R \& D$, production, and sales bases. Investment in local production with direct overseas sales remains important for efficiency and cost reduction, because of preferential taxation and foreign exchange rates. The establishment of wholly owned subsidiaries and manufacturing plants also is extremely important in future strategies Yamanouchi and Fujisawa already are constructing manufacturing plants to produce their own pharmaceuticals.

Several companies have begun to acquire local enterprises that offer bases for overseas development, production, and sales. However, joint venture projects are as actively pursued as mergers and capital participations. Approval of new drugs in Europe is easier to obtain if Japanese companies have joint ventures with European pharmaceutical companies. Moreover, expanding joint ventures with China, where the population exceeds 1 billion, portends large growth potential as well as improvements in China's health care system. Japan's direct investments in China grew by $78 \%$ in 1995 , outstripping U.S. investments by $40 \% .{ }^{22}$

The key to success in overseas markets is the development of new acceptable drugs. To achieve this goal, Japanese pharmaceutical companies must establish advanced research facilities and cooperation of laboratories in joint venture enterprises and universities. Such strategies expedite new drug approval and patent applications and stimulate development projects, while allowing for shared risk."

Additionally, Japanese pharmaceutical companies must enhance their research efficiency and acquire their own specialties. Sankyo's Melavotin and Fujisawa's Prograf are proof of the potential for new international blockbuster drugs in coming years. Thus, $R \& D$ becomes more important regardless of increasing costs and longer timelines for bringing new products to market.

\section{OUTLOOK FOR THE JAPANESE PHARMACEUTICAL INDUSTRY}

\section{Transition of Drug R\&D Along With the Aging of Society}

Japanese pharmaceutical companies have succeeded in developing antibiotics that have proved extremely effective in the treatment of tuberculosis, pneumonia, and other infectious diseases. In the 1980s, sales of antibiotics were higher than sales of any other drugs and comprised $27 \%$ of Japan's total drug sales. Since then, Japan has become a leading country for the production of antibiotics worldwide.

However, the aging of the Japanese population has increased the incidence of adult, geriatric, and chronic diseases, rather than infectious and acute ailments. In 1989, the production of drugs for the circulatory system occupied $14 \%$ of Japan's total market, surpassing antibiotics at $13 \%$. Now, 
International Movement of Japan's Pharmaceutical Industry: Reform of Japanese Health Policies, Part III

Table 4. Death Rates in Japan by Five Principal Causes (Rate Per 100,000 population)

\begin{tabular}{|c|c|c|c|c|c|}
\hline Year & Cause 1 & Cause 2 & Cause 3 & Cause 4 & Cause 5 \\
\hline 1950 & $\begin{array}{l}\text { Tuberculosis } \\
146.4\end{array}$ & $\begin{array}{l}\text { Cerebrovascular Disease } \\
127.1\end{array}$ & $\begin{array}{l}\text { Pneumonia and Bronchitis } \\
93.2\end{array}$ & $\begin{array}{l}\text { Gastritis and Enteritis } \\
82.4\end{array}$ & $\begin{array}{l}\text { Malignant Neoplasms } \\
77.4\end{array}$ \\
\hline 1960 & $\begin{array}{l}\text { Cerebrovascular Disease } \\
160.7\end{array}$ & $\begin{array}{l}\text { Malignant Neoplasms } \\
100.4\end{array}$ & $\begin{array}{l}\text { Pneumonia and Bronchitis } \\
93.2\end{array}$ & $\begin{array}{l}\text { Heart Disease } \\
73.2\end{array}$ & $\begin{array}{l}\text { Senility } \\
58.0\end{array}$ \\
\hline 1970 & $\begin{array}{l}\text { Cerebrovascular Disease } \\
176.5\end{array}$ & $\begin{array}{l}\text { Malignant Neoplasms } \\
116.8\end{array}$ & $\begin{array}{l}\text { Heart Disease } \\
87.0\end{array}$ & $\begin{array}{l}\text { Accidental Death } \\
42.6\end{array}$ & $\begin{array}{l}\text { Senility } \\
38.2\end{array}$ \\
\hline 1980 & $\begin{array}{l}\text { Cerebrovascular Disease } \\
139.5\end{array}$ & $\begin{array}{l}\text { Malignant Neoplasms } \\
139.1\end{array}$ & $\begin{array}{l}\text { Heart Disease } \\
106.2\end{array}$ & $\begin{array}{l}\text { Pneumonia and Bronchitits } \\
33.7\end{array}$ & $\begin{array}{l}\text { Senility } \\
27.6\end{array}$ \\
\hline 1987 & $\begin{array}{l}\text { Malignant Neoplasms } \\
164.1\end{array}$ & $\begin{array}{l}\text { Heart Disease } \\
118.3\end{array}$ & $\begin{array}{l}\text { Cerebrovascular Disease } \\
101.7\end{array}$ & $\begin{array}{l}\text { Pneumonia and Bronchitis } \\
44.9\end{array}$ & $\begin{array}{l}\text { Accidental Death } \\
23.0\end{array}$ \\
\hline 1992 & $\begin{array}{l}\text { Malignant Neoplasms } \\
231.7\end{array}$ & $\begin{array}{l}\text { Heart Disease } \\
175.3\end{array}$ & $\begin{array}{l}\text { Cerebrovascular Disease } \\
117.9\end{array}$ & $\begin{array}{l}\text { Pneumonia and Bronchitis } \\
80.2\end{array}$ & $\begin{array}{l}\text { Accidents or Poisonings } \\
34.4\end{array}$ \\
\hline
\end{tabular}

Source: International Pharmaceutical Service

patients with diseases associated with aging outnumber those with contagious diseases by $8: 1,23$. In 1992, cancer caused 231,786 deaths in Japan; heart disease caused 175,336 deaths; cerebrovascular disease accounted for 117,908 deaths; and 80,214 died from pneumonia and bronchitis (see Table 4). Cancer became the second most frequent cause of death in 1953 and the leading cause of death in 1981; one out of every four deaths in Japan now is attributed to cancer. Heart disease surpassed cerebrovascular disease in 1985 to become the second leading killer. Cerebrovascular disease also was increasing, but emphasis on suitable diet and effective drugs has slowed this trend. ${ }^{5}$

Today, R\&D in Japan focuses on the treatment of cancer, cardiovascular diseases, cerebrovascular disease, senile dementia (such as Alzheimer's disease), and osteoporosis, which are all age related. In addition, fourth-generation antibiotics, which are effective against drug-resistant bacterium in new forms of tuberculosis and sexually transmitted diseases, also are important for new drug development.

\section{BIOTECHNOLOGY DEVELOPMENT}

Japan's Ministry of International Trade and Industry (MITI) has encouraged the development of biotechnology since $1981 .{ }^{2+} \mathrm{MITl}$ maintained a strong export orientation from the early postwar period but historically lacked involvement with the pharmaceutical industry, whose provenance remained firmly within the Ministry of Health and Welfare (MHW). Japanese manufacturers hope that combining molecular biology and high technology will result in numerous new drugs and may provide fundamental cures for genetic diseases, cancer, and AIDS, among others.

A series of new biodrugs has been developed and is entering extensive practical stages, including interferon, insulin, human growth hormone, thrombolytic agents, erythropoietin hormone for renal anemia, and the leukocyte proliferation factor G-CSF for the treatment of leukopenia after chemotherapy. Japan still imports $80 \%$ of biotechnology to produce biodrugs. According to Nikkei Biotechnology, the market of biodrugs in Japan reached sales of 581 billion yen in 1994, similar to that of the United States. ${ }^{25}$ Thus, Japan has to improve its own biotechnical engineering to become a strong contender in the pharmaceutical industry and increase profits.

\section{EXPANSION OF \\ PHARMACEUTICAL MARKETING INTO SOUTHEAST ASIA}

The pharmaceutical market has expanded by $10 \%$ per year worldwide in recent years. The three largest markets - the United States, Europe, and Japan-comprise $80 \%$ of worldwide sales. Southeast Asia, together with China, consumes approximately $8 \%$ of the world's pharmaceuticals and has become the fourth largest pharmaceutical market ${ }^{6}$ and the fastest growing.

Asia's newly industrialized countries, such as Singapore, South Korea, Taiwan, and Hong Kong, have become attractive pharmaceutical markets because of high per capita incomes and fairly well-developed health service systems. Traditionally, the most demanded pharmaceuticals in Southeast Asia have been antibiotics. Governments have spent the majority of their funds on antibiotics, vaccines, vitamins, and 
International Movement of Japan's Pharmaceutical Industry: Reform of Japanese Health Policies, Part III

Continued from page 580

blood products. However, as the area's economies have advanced, the demand for gastrointestinal, respiratory, and contraceptive preparations has increased. Many foreign pharmaceutical firms have chosen to compete in the markets of Southeast Asia through joint ventures and local distributors, because local firms are more familiar with marketing channels and consumer expectations.

A major barrier for foreign competitors in the Southeast Asian market is the lack of patent protections. China is one of the worst patent offenders in the world; generic and pirated drugs constituted $90 \%$ of the Chinese market in 1992. ${ }^{6}$ Restrictions on distribution also are very frustrating. Foreign companies must partner with local joint ventures and cannot cooperate with other foreign firms or implement their own distribution operations. ${ }^{13}$ Such regulations make it more difficult for foreign pharmaceutical firms to establish wholly owned subsidiaries in Southeast Asian countries and may make an effective market nearly impossible. Despite these barriers, however, the Southeast Asian pharmaceutical market holds great promise for Japanese and Western firms.

\section{THE RECENT PACIFIC RIM CRISIS}

The panic in the Asian financial markets this past year shook the global economy. ${ }^{26}$ This region's once booming economies were shaken by a plummeting stock market and collapsing currency. Given that the world's industries and financial systems are intricately intertwined, the current growth in U.S. production, employment, and exports is being threatened by this Asian crisis. Both the United States and Europe now seek greater coordination with Japan to mount a coherent response to the Asian financial crisis. The course of this policy redirection holds implications for the global pharmaceutical industry.

In the early months of 1998 , as the International Monetary Fund (IMF) began imposing new conditions on the
Asian nations, resistance mounted. With currency devaluations, cheaper foreign imports likely will flood Western markets, to further exacerbate already climbing trade deficits there. A piece of the imposed new framework on Asia would force sweeping restructuring of basic industries, loosening what Safire ${ }^{27}$ calls the "crony capitalism" of Japaris keiretsu, Korea's chaebol, China's guanxi, and Suharto's family ties throughout Indonesia. New IMF regulations might break down long-standing cultural barriers to the West and create freer markets for trade. However, as economies contract in China, Korea, Taiwan, the Philippines, Thailand, Indonesia, Singapore, and even Japan, the richer West will face weaker demand for its exports, at least in the near term. ${ }^{28}$ Japan may be hurt the most because it exports more within Asia than do America and Europe, particularly when measured by percentage of Japan's GDP, $4.4 \%$.

Thus, Japanese pharmaceutical manufacturers face new obstacles to overseas markets by the year 2000 , and increased challenge by Western companies for the Japanese domestic market. Simply put, Japanese pharmaceuticals may be relatively cheaper in the West, but monies for export purchases, especially in the public health systems of their trading partners, may not be as plentiful across the Asian markets. Western drugs may be more expensive for Japanese consumers (or rather the Ministry of Health $\&$ Welfare), but the barriers to the domestic market may ease to promote more imports.

\section{FINANCIAL TURMOIL IN JAPAN}

Japan has been said to be the "most consistently misunderstood, misinterpreted country on earth, a place where nothing is ever quite as it seems. ${ }^{\text {"29 }}$ This description is easy to accept when surveying the turmoil that Japan is facing on its own, beyond the broader crisis across Asia. As The Economist editorialized in March of this year:
"Once, Japan invited admiration, which was deserved, if at times exaggerated. Now, however, it invites despair as it fails to escape from the economic stagnation of this lost decade, fails to reform its shaky politics and corrupt bureaucracy, and fails as a result to be able to lead East Asia out of its troubles. At times, that despair has looked itself exaggerated. But not now, for the latest figures show that Japan has entered its first economy-shrinking recession for almost 25 years; and the latest news suggests that no one in authority is capable of doing much about it." ${ }^{130}$ As international confidence in Japan's economy, banks, and state apparatus wanes, its foreign relationships will suffer, most notably with the United States. To recapture confidence, Japan may have to yield to greater policy changes demanded by the Clinton administration. As he struggles to justify the commitment of billions of dollars to the IMF to prop up the victims of the Asian currency crisis, President Clinton's limited success with fast-track trade negotiating authority does not assure speedy worldwide trade liberalization. ${ }^{31}$ Fast-track authority would allow the administration to submit trade pacts to Congress for either an up or down vote without amendments, which greatly strengthens U.S. negotiating power with trade partners.

The ongoing Japanese turmoil reaches beyond the potential to cause problems for the world pharmaceutical industry. Some economists fear that if Japan cannot pull itself and its region back together soon, it might drag the United States and Europe into recession. ${ }^{32}$ With more and cheaper Asian exports washing onto American shores, U.S. corporate profits are likely to erode as sales decline throughout Asian nations. The impact on Wall Street would be certain to abruptly halt consumer spending as prosperous portfolios fall. Under this scenario, Asian investors would dump their U.S. treasuries to provoke federal intervention, interest rates would rise, monetary and fiscal policy 
interventions in the midst of partisan bickering would further complicate matters, and corporate downsizing would lead to the end of the longest lasting peacetime expansion ever for both the United States and the rest of the West.

The next year will show whether Japan's leadership can reverse the plunge. Western powers hoped the $\$ 75$ billion stimulus plan by Ryutaro Hashimoto would reform Japanese society "toward the kind of market capitalism practiced in the U.S. and Britain." ${ }^{29}$ (Hashimoto's administration has been replaced.) Such a direction involves a complex undoing of the bureaucratic management of the economy, which outside commentators maintain is responsible for problems in the Ministry of Finance and the financial sector. With entry barriers lowered, Deutche Bank, Citibank, Merrill Lynch, and other Western multinationals are eager to gain access to the $\$ 11$ trillion in savings held by the Japanese. Hashimoto's tax cuts and public spending programs were designed to stimulate sluggish demand for consumer goods amidst this historically high savings for retirement. Slow growth will force Japanese producers to compete more effectively abroad. A boomlet of mergers and acquisitions (M\&A) may follow the American banking M\&A fever. ${ }^{24}$ Although culturally, market reverses manifest themselves differently in Japan-for instance, mass layoffs do not follow mergers there-its corporations may align their interests more strongly with stockholders to pursue improvements in return on investments. Traditionally, growth has been stressed more than profits. As fast as they come, these economic developments will take hold in the Japanese pharmaceutical industry and affect their overseas strategies.

\section{INTERNATIONAL HARMONIZATION}

International harmonization of pharmaceutical regulations has been a protracted process, ${ }^{33}$ and Japan has not been in its forefront. Historically, the MHW has been responsible for deciding policy for the Japanese pharmaceutical industry, focusing primarily on domestic health affairs; however, the MHW has not been adequately supportive on overseas policies. For example, Southeast Asian countries generally do not recognize Japanese drug approval as equal to drug approval in the United States, which results in the automatic approval of competing products in certain Southeast Asian countries. The Japanese pharmaceutical industry blames an ineffective MHW for failing to explain Japanese drug approval policy to trading partners.

Japanese clinical trials are not readily accepted by regulatory authorities in the United States or Europe. In Japan, the efficacy of new drugs is compared to that of drugs already used for that indication; if the new drug produces the same or better results, it is approved. In contrast, FDA marketing approval is based on comparisons of new drugs with placebos, while Japanese clinicians tend to resist the use of placebo trials. As long as such problems persist, Japanese pharmaceutical companies will have to conduct clinical trials overseas-often through licensing or joint ventures-to deal with regulatory obstacles. The international harmonization of regulatory standards will ease these difficulties.

At the end of November 1995, the Third International Conference on Harmonization Convention of medical products in Japan, the United States, and Europe took place in Yokohama. ${ }^{1}$ Progress on unifying standards will speed up approval of new drugs by eliminating unnecessary tests on quality, safety, and effectiveness. Further, the harmonization of patent policies will improve the R\&D environment. The international harmonization of regulations is essential to the globalization of the Japanese pharmaceutical industry.

\section{CONCLUSION}

The Japanese are just now becoming skilled in the American pharmaceutical market, though they have a much stronger presence throughout Asia. In the 1980s, Japanese pharmaceutical manufacturers began to establish wholly owned subsidiaries, manufacturing plants, and research facilities in other countries to develop an institutional capacity to sell their products in overseas markets and to innovate internationally acceptable drugs. Domestically, pressures had intensified because of curbed drug prices intended to reduce government health expenditures and from competition with foreign pharmaceutical firms.

Despite the recent financial crisis, Japanese pharmaceutical manufacturers will regroup and continue their overseas expansion as Japan assures its place as the second largest nation for drug production.

\section{References}

1. Takahashi S. Japan's pharmaceutical industry contributing to world health. JAPAN 2 lst 1995(Aug): 24-27.

2. Chevalier K, Salmon JW. International movement of Japan's pharmaceutical industry: reform of Japanese health policies. Part 1. J Managed Care Pharm 1997; 3(6): 667-74

3. Chevalier K, Salmon JW. International movement of Japan's pharmaceutical industry: reform of Japanese health policies. Part II. J Managed Care Pharm 1998; 4(2): 123-37.

4. Goto, T. The globalization of Japan's pharmaceutical industry. JAPAN 21 si 1995(Aug): 21-23

5. Takahashi, S. Japan's pharmaceutical industry JAPAN 21st 1994(Aug): 18-23.

6 . Howe, D. The pharmaceutical industry in southeast Asia. J Southeast Asia Business

1992(Winter); 8: 73-97.

7. Takahashi, S. Japan's leading pharmaceutical enterprise working for a brighter future: interview with Kenkichi Murakami, member of the board,

Takeda Chemical Industries, Lid. JAPAN 21st 1994(Aug): 24-25.

8. Sankyo out to develop new medicines after Mevalotin. JAPAN 21 st 1994(Aug): 28-29.

9. Sankyo moves quickly into the international marketplace. JAPAN 21st 1994(Aug): 32

10. Yamanouchi Pharmaceutical readies itself for globalization. JAPAN 2 lst 1995(Aug): 30.

11. Yamanouchi's pharma sales up $8 \%$. SCRIP

2172, Oct 15, 1996: p. 10.

12. Japan's drug industry: medicinal madness. The Economist 1993(March): 73.

13. Luo AY, Salmon JW, Lambert B. U.S. pharmaceutical firm prospects within the People's

Republic of China. J Managed Care Pharm 1996; 2: $76-82$.

14. Yamanouchi completes Chinese factory. SCRIP 
2242, June 20, 1997: p. 19

15. Takahashi, S. Delivering seven major new products to the world market by 2005: interview with Masayoshi Onoda, president of Yamanouchi Pharmaceutical Co., Lid. JAPAN 21st 1994(Aug): 28-29

16. Fujisawa's drug sales down $7 \%$. SCRIP 2172 , Oct 15, 1996: p. 7

17. Fujisawa Pharmaceutical has high hopes for the future. JAPAN 2 lst 1994(Aug): 34

18. Eisai's tripolar research system contributes to world health. JAPAN 2 l.st 1994(Aug): 33.

19. Daiichi Pharmaceutical ambitious to capture world's synthetic antibacterial agent market. JAPAN 21st 1995(Aug): 31

20. Daiichi Pharmaceutical Co. Ltd.: enriching the quality of life. JAPAN 2 lst 1994(Aug): 35
21. Takahashi S. Contributing to the health of people throughout the world: interview with Osamu Nagayama, president of Chugai Pharmaceutical Co., Ltd. JAPAN 2 lst 1994(Aug): 30-31

22. Koretz G. A marriage made in Asia: SinoJapanese ties worry the U.S. Business Week, Jan 29,$1996 ; 20$

23. Reich MR. Why the Japanese don't export more pharmaceuticals: health policy as industrial policy. California Management Review

1990(Winter): $124-50$.

24. Spindle B. Merger boomlet takes hold in Japan. Wall Street Journal, April 13, 1998: A18 25. Biolechnology in Japan: alien culture. The Economist, Nov 18, 1995: 79

26. Variable fallout. The Economist, Nov 29 , 1998: $78-80$.
27. Safire W. Crony capitalism. New York Times Magazine, Feb 1, 1998: 16-18

28. Bremner T, el al. What to do aboul Asia. Business Week, Jan. 26, 1998: 27-30

29. Murphy RT. Don't be fooled by Japan's big bang. Fortune, Dec 29, 1997:214-34

30. The Japan puzzle. The Economist, March 21 1998: 15 .

31. Calmes J, Greenberger, RS. For Clinton, sum mit is challenge after trade setback. Wall Street Journal, Nov 20, 1997: A24

32. Schlesinger JM. Fault lines: behind the U.S. rift with Japan. Wall Street Joumal, April 13, 1998 A2-3.

33. Spivey RN, Wertheimer AI, Rucker TD International pharmaceutical service. New York: Binghamion, 1992

\section{AMCP's Web Site ... See It for Yourself!}

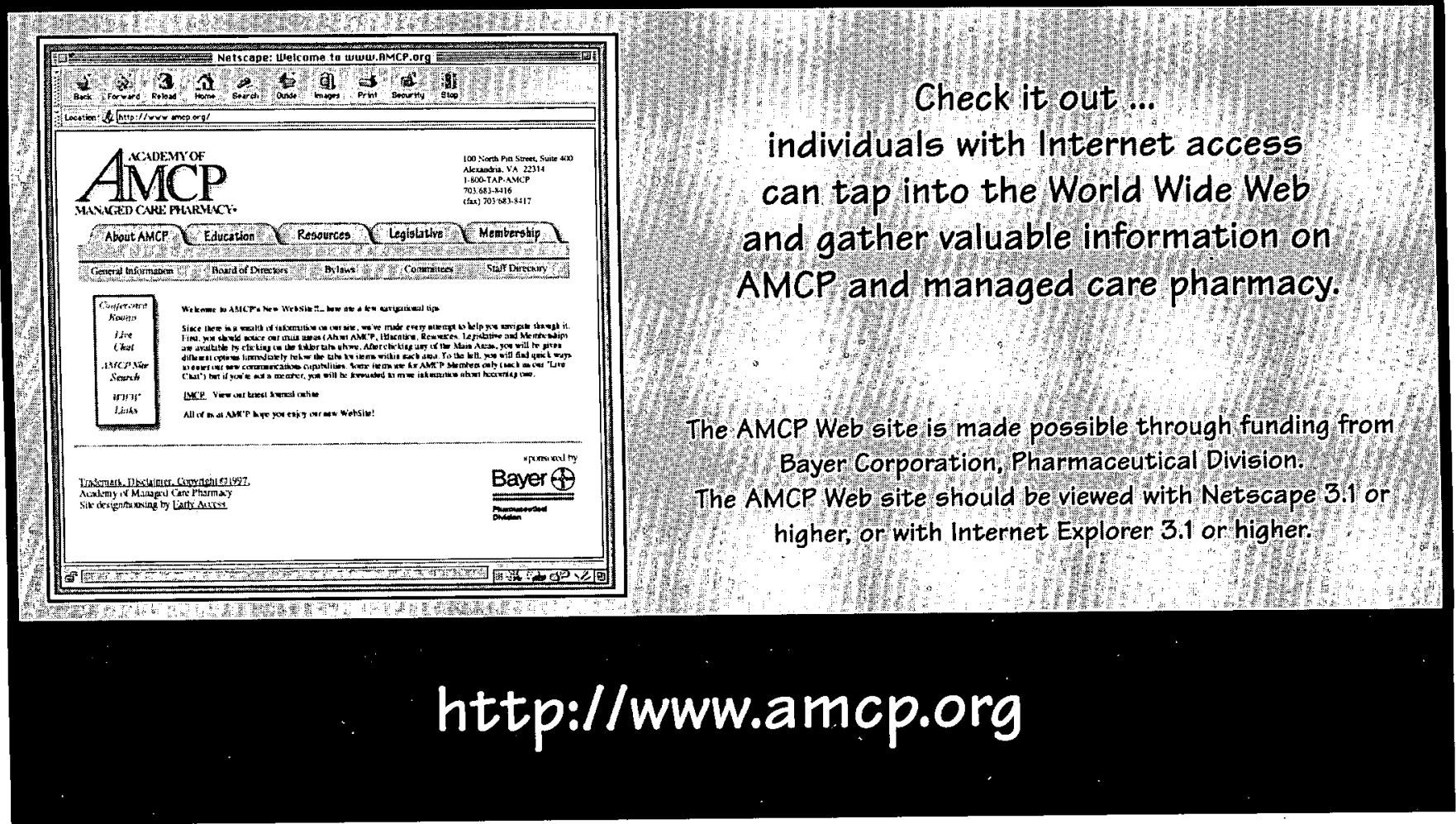

